\title{
Evaluating Kpk - Bpkp Coordination and Supervision Join Program in Corruption Prevention in The Mining Sector (Kirkpatrick Model Approach)
}

\author{
By
}

\author{
Iswan Elmi, R. Madhakomala, Hamidah \\ Universitas Negeri Jakarta
}

Article History: Received: 11 January 2021; Accepted: 27 February 2021; Published online: 5 April 2021

\begin{abstract}
This study focuses on the corruption prevention strategy implemented by Korsupgah (Coordination and Supervision for Corruption Prevention) within the mining sector by giving emphasize on the process of reactions, learning, and behavioral changes in anti-corruption which aimed at reducing the corruption level as the result of the program. The research evaluates Korsupgah program by describing the importance of corruption prevention and measuring the effectivenss of Korsupgah Program (in the form of EPK Indices) in the mining sector reflected by anti-corruption behavioral changes of the mining actors. Herewith, the EPK indices are used as one of the criteria and indicator for corruption prevention program implementation.
\end{abstract}

The study population consists of the Civil State Apparatus (ASN) in the provincial government units which are the Office of Environmental, Office of Energy and Mineral Resources (ESDM), Inspectorate, and Integrated One-Stop Service Center (Pelayanan Terpadu Satu Pintu abbreviated as PTSP) in Bangka Belitung, South Kalimantan, and South Sumatra, as well as Coordination and Supervision for Corruption Prevention (Korsupgah) Team in BPKP which in total amounting of 251 persons. The study employs a Structural Equation Model using SEM AMOS Ver. 24. The study concludes that: 1) The korsupgah capability positively and significantly affects case handling; 2) the program implementation positively and significantly affects case handling; and 3) the program implementation positively and significantly affects the capability.

The study evaluates four stages of Kirkpatrick Model and confirms that: 1) Reaction: the study shows that mining actors' response towards special purpose audit (Audit Tujuan Tertentu abbreviated as ATT) is adequate (prevention); 2) Learning: the study shows that learning process of Korsupgah Program (prevention) has been already in progress. 3) Behavior: the study shows that the behavioral change to follow up on the finding result of ATT Korsupgah has been observed. 4) Result: the study shows that the Corruption Perception Index is still low, Public Complains and corruption cases in mineral and coal mining still exist.

Key words: Corruption prevention through the process of reactions, learning, behavior and result

\section{Background}

The long-existing problem that the Indonesians have been facing is elitist corruption (undertaken by parties who have the opportunity to dominate the economic sources), systemic (involving a lot of interests and people), and political (still presented as political rhetoric), which to some extent reflected in the Anti-Corruption Perception Index that is still low compared to other countries, in ASEAN level or Asia. It mauy caused by the proliferation of various corruption practices within various development sectors, the lack of visibility of deterrent effect from the effort to sanction corruption practices, and the sub-optimum performance of corruption prevention efforts. Therefore, if the ongoing corruption cases in public and the government are not being handled seriously, it will lead to social problems that are destructive to social order and value system within our society and government (John Clamer, 2012: 113-132). To overcome the problem, there has to be a shift in a paradigm of corruption handling through an anti-corruption behavioral change.

Changing the public behavior towards anti-corruption is still a great problem and challenge that people in our time still have to work on. Our shared-responsibility is to push the behavioral change. Corruption as a social problem is a serious issue that needs to be handled collectively and collaboratively in an integrated approach by the parties involved in it. The first step to identify and analyze the corruption problem is to map the "nature" or the anatomy 
of corruption itself. Hence, the activities in mapping and comprehensive analysis on corruption must produce the classification of corruptions that concurrently taking place and predict the future potential of it; the root cause and the impact that it brings about; increasing public awareness through developing the soft and hard competence of the human resource, and the grand design strategy to implement corruptive behavioral change.

Research shows that the real impact of corruption's prevalence leads to the hindrance of the human development due to income, education, and health discrepancies (Ortega et. al., 2014: 974-975). The interesting question is whether the low quality of the Human Resource or corruption that makes Human Resource development hampered.

Corruption prevention effort shall be done continuously and evaluated periodically using the metrics of economic, efficiency, and effectiveness. By this, to measure the effectiveness of the corruption prevention program execution, Badan Pengawasan Keuangan dan Pembangunan (abbreviate as BPKP) initiates to develop a measuring instrument in the form of Corruption Preventive Effectiveness Index (Indeks Efektivitas Pencegahan Korupsi, abbreviated as EPK). The referred measurement model is developed from evaluation result as an effort from BPKP in taking part to eradicate corruption according to Presidential Regulation Number 192 Year 2014 on Financial and Development Supervisory Agency (BPKP).

The EPK Index Development is motivated by the awareness that in the effort to reach the strategic goals and to manage corruption eradication effort, progress measurement and assesment framework is needed. This framework will be used as the foundation in composing the road map of how to increase the corruption eradication effectiveness. This index can be used to measure effectiveness in corruption preventive programs in all fields or sectors, whether it is public sector or corporation that involves in all economic, social, environmental, and public development.

To answer the aforementioned question, this research evaluated three aspects which are 1) mining actors (human capital) aspect, 2) mining business process, and 3) cultural values in the mining industry. The research assumes that the level of success in managing these aspects is the key success factor in shifting changes into an anticorruption behavior and minimizing corruption practices in the mining business which can lead to the mining sector's purpose attainment in producing welfare to all public layers.

Researchers argue that the problem of anti-corruption management in the mining sector shall be resolved soon through agenda-setting and the using of the adequate instrument of corruption prevention in an effective manner. Corruption prevention will be implemented through a series of policies in Human Resources Management via competency and professionalism improvement for mining actors, increasing transparency of the mining business process, and strengthening of anti-corruption value and culture in the sector .

By strengthening the above-mentioned three aspects, it is expected that a competitive, transparent, and accountable mining sector will be promoted which in turn will affect reducing corruption practices and create changes in mining actors behavior toward anti-corruption value. Fail to do so, it is assumed that it will bring collateral impact one of which is the increase of corruption practices in the mining sector.

Although policies and strategies for eradicating corruption The long-existing problem that the Indonesians have been facing is elitist corruption (undertaken by parties who have the opportunity to dominate the economic sources), systemic (involving a lot of interests and people), and political (still presented as political rhetoric), which to some extent reflected in the Anti-Corruption Perception Index that is still low compared to other countries, in ASEAN level or Asia. This state is caused by the proliferation of corruption practices conducted in various forms within various development sectors, the lack of visibility of deterrent effect from the effort to sanction corruption practices, and the sub-optimum performance of corruption prevention efforts. Therefore, if the ongoing corruption cases in public and the government are not being handled seriously, it will lead to social problems that are destructive to social order and value system within our society and government (John Clamer, 2012: 113132). To overcome the problem, there has to be a shift in a paradigm of corruption handling through an anticorruption behavioral change.

Changing the public behavior towards anti-corruption is still a great problem and challenge that people in our time still have to work on. Our shared-responsibility is to push behavioral change that is mentioned. Corruption as a social problem is a serious issue that needs to be handled collectively and collaboratively in an integrated approach by the parties involved in it. The first step to identify and analyze corruption problem is to map the "nature" or the 
anatomy of corruption itself. Hence, the activities in mapping and comprehensive analysis on corruption must produce the classification of corruptions that concurrently taking place and predict the future potential of it; the root cause and the impact that it brings about; increasing public awareness through developing Human Resource soft and hard competence, and the grand design strategy to implement corruptive behavioral change.

Research shows that the real impact of corruption's prevalence leads to human development obstruction due to income, education, and health discrepancies (Ortega et. al., 2014: 974-975). The interesting question is whether the low Human Resource quality or corruption makes Human Resource development hampered.

Corruption prevention effort shall be done continuously and evaluated periodically using the metrics of economic, efficiency, and effectiveness. With this, to measure the effectiveness of the corruption prevention program execution, Badan Pengawasan Keuangan dan Pembangunan (abbreviate as BPKP) initiates to develop a measuring instrument in the form of Corruption Preventive Effectiveness Index (Indeks Efektivitas Pencegahan Korupsi, abbreviated as EPK). The referred measurement model is developed from evaluation result as an effort from BPKP in taking part to eradicate corruption according to Presidential Regulation Number 192 Year 2014 on State Development Audit Agency (BPKP).

The EPK Index development is motivated by the awareness that in the effort to reach the strategic goals and to manage corruption eradication effort, progress measurement and assesment framework is needed. This framework will be the foundation in composing the roadmap to the improvement of the corruption eradication effectiveness. This index can be used to measure effectiveness in corruption preventive programs in all fields or sectors, whether it is bureaucracy or corporation that involves all economic, social, environmental, and public development.

To answer the aforementioned question, this research will evaluate three aspects which are 1) mining actors (human capital) aspect, 2) mining business process, and 3) Cultural values in the mining industry or mining culture aspects. The research assumes that the level of success in managing these aspects is the key success factor in shifting changes into an anti-corruption behavior and minimizing corruption practices in the mining business which can lead to the mining sector's purpose attainment in producing welfare to all public layers.

Researchers argue that the problem of anti-corruption management in the mining sector shall be resolved soon through agenda-setting and the using of an adequate instrument of corruption prevention in an effective manner. Corruption prevention will be implemented through a series of policies in Human Resources Management via competency and professionalism improvement for mining actors, increasing transparency of the mining business process, and strengthening of anti-corruption value and culture in the sector (The Mining Culture).

By strengthening the above-mentioned three aspects, it is expected that a competitive, transparent, and accountable mining sector will be promoted which in turn will affect reducing corruption practices and create changes in mining actors behavior toward anti-corruption value. Fail to do so, it is assumed that it will bring collateral impact one of which is the increase of corruption practices in the mining sector.

Although the eradicating corruption policies and strategies are set out to carry out preventive and represive measures in parallel and simultaneously, in their current implementation, law enforcement officials still focus on the repressive approach. Therefore, it is important to also promote the preventive aspect by creating an anticorruption behavior, improving the system, and building an anti-corruption culture as the essence of its strategy.set out to carry out prevention and prosecution of corruption in parallel and simultaneously, in their current implementation, law enforcement officials still focus on the approach to prosecuting corruption. Therefore, it is an urge to also promote the preventive aspect by creating an anti-corruption behavior, improving the system, and building an anti-corruption culture as the essence of its strategy.

\section{Theoretical Study}

This study refers to several theoretical studies carried out by experts, namely Nkwake (2015) for evaluation, Weiss (2016) for program evaluation, Royse et. al. (2010) for motivation, Revolida (2010) and Novianti (2013) describe the characteristics of the mining sector, Dietric (2013) for coordination, Saltiel (2016) for supervision, Hussein Alatas (1982) for corruption, Stephenson (1992) for capability, Van Brabant (2015) for authority, Flamholz (1985) for management control, David (2014) and Wibowo (2007) for competence, Kim and Davis (2018) for questionnaires, Zainal Arifin (2010) for questionnaires. Besides, several expert opinions have strengthened this 
research, including Shipman (1989), Singleton (2006), Schuck (2014), Hamzah (2005), Cambridge (2017), Wang and Zeng (2017), Nely et. al. (2000), Lizzio and Wilson (2004), Propescu and Omran (2011), Hampton (2009), Albrecht et. al. (2011).

\section{Korsupgah KPK-BPKP Program Concept in the Mining Sector}

To enter the mining business, a mining permit from the Government is required both from the National and Regional level in the form of a Mining Business License (IUP). There are 4 (four) categories of permits issued related to mining businesses, namely Exploration IUP, Production Operation IUP, People's Mining Permit (IPR), and Special Mining Business Permit (IUPK).

Experts opinion regarding the characteristics of the mining sector is provided by Novianti (2013) where she states that the mining sector has several characteristics, namely 1) non-renewable natural resources; 2) Has high business risks in the form of geological risk, cost uncertainty risk, market risk, namely the fluctuation of mining prices and the risk of changes in government policies; and 3) there is a negative impact on the quality of the environment and the development of the community around the mine. Another expert, Revolida (2010), describes several characteristics of the mining sector, namely 1) non-renewable natural resources, 2) in general, location of activities in remote areas, and 3) high risk where the level of exploration success is still low and requires high costs. and the latest technology to mine it.

On the other side, Indonesian Financial Accounting Standard, PSAK No. 33 -Accountancy for General Mining explains the traits and characteristics of the general mining industry, namely 1) exploration of general mining materials is an activity that has high uncertainty, 2) minerals are depletion and non-renewable, 3) are located in remote areas and their activities cause environmental damage and/or pollution, and 4 ) the Indonesian government does not provide mining concessions.

Macro-level studies in the mining sector will become the basis for guidelines and implementation references at the mining company level (micro-level) such as strengthening professional and competent mining human resources, revitalizing governance in mining companies reliably and credibly, and creating a climate or culture of mining companies that are not corrupt and sustainable.

\section{Conception of Corruption Prevention}

Juridically, the meaning of corruption, both definition and type, is regulated in Article 30 of Law Number 31 Year 1999 jo. Law Number 20 Year 2001 on Eradication of Corruption Crime (Anti-Corruption Law). In a juridical sense, the definition of corruption is not only limited to actions that comply with the formulation of offences that can harm the state finances or the state economy but also includes actions that fulfil the formulation of offenses, which harm the public or individuals. Therefore, based on the type of criminal acts, corruption can be grouped into 1) offenses that result in the loss to the state finances or the country's economy; 2) bribery (active or passive), 3) embezzlement; 4) extortion as abuse of power; 5) falsification; and 6) offenses related to contracting, suppliers and contractors.

Corruption has been plaguing Indonesia for a long time and has almost touched all aspects of people's lives. It seems that corruption has reached what Robert Klitgaard (2005) calls a "culture of corruption" because it is considered normal, such as in everyday life, where to speed things up, someone usually gives "facilitation payments" or the habit of giving cigarette money, and provide facilities and prizes. Furthermore, based on the factors of corruption, Syed Hussein Alatas (1982) said that the factor of corruption is the absence or weakness of leadership in key positions that can influence behavior that tames corruption, lack of religious and ethical education, low levels of public education, poverty, and the condition of society that is conducive to growing corruption".

Furthermore, theoretically, corruption is related to fraud. Conceptually, we recognize the concept of the fraud triangle. The first factor is pressure in the form of motivation to commit fraudulent actions. Generally, pressure arises out of need or financial problems, but many are driven only by greed. Then, the second factor is the chance or opportunity to commit fraud or corruption due to the inadequacy of the internal control system. And lastly, the third factor, namely rationalization where a person looks for justification for his fraudulent activities. The perpetrators of fraud believe or feel that their actions are not cheating (Singleton, 2006; 8-9).

Apart from the various perceptions above, based on the results of BPKP's research, various aspects of the causes of corrupt acts were identified, namely 1) individual aspects of the perpetrators of corruption; 2) organizational aspects in a broad sense, 3 ) aspects of society where individuals and organizations are located; 4) aspects of laws and regulations that cause corruption to easily occur. 
Looking at the definitions, causal factors, types of corruption and fraud, as well as the results of the BPKP research above, it turns out that the causes of corruption are very multidimensional and in other words, corruption is closely related to the various factors that stimulate it or various factors behind it. Because it takes extra effort from all parties to prevent it.

\section{Corruption Prevention Effectiveness Index (EPK)}

The criteria for the effectiveness of corruption prevention programs in both the bureaucratic and corporate environments are framed in the EPK Index measurement. The use of the EPK Index in evaluating the program is not as shown in the table below.

\begin{tabular}{|c|c|c|}
\hline Variable & Dimension & Indicator \\
\hline \multirow{12}{*}{$\begin{array}{l}\text { Corruption Risk } \\
\text { Management } \\
\text { Capability }\end{array}$} & \multirow[t]{3}{*}{ Capacity } & 1. Corruption risk management policy \\
\hline & & 2. The organizational structure of corruption risk \\
\hline & & 3. Anti-corruption behavior standards \\
\hline & \multirow[t]{3}{*}{ Authority } & 4. Decision making in managing corruption risk (power to) \\
\hline & & 5. Awareness to manage risk (power within); \\
\hline & & 6. Partnerships and collaboration to prevent corruption (power with) \\
\hline & \multirow[t]{3}{*}{ Competence } & 7. Employee anti-corruption competence \\
\hline & & 8. Competence of anti-corruption second line of defense officers \\
\hline & & $\begin{array}{l}\text { 9. Anti-corruption competence of service users, customers, } \\
\text { providers of goods / services and the public }\end{array}$ \\
\hline & \multirow[t]{3}{*}{ Ability } & 10. Human Resources \\
\hline & & 11. Finance \\
\hline & & 12. Facilities and infrastructure \\
\hline \multirow{12}{*}{$\begin{array}{l}\text { Implementation } \\
\text { of the Prevention } \\
\text { Strategy for } \\
\text { Corruption }\end{array}$} & \multirow[t]{3}{*}{ Integrity } & 13. Individual Integrity \\
\hline & & 14. Organizational Integrity \\
\hline & & 15. Institutional Integrity \\
\hline & \multirow{3}{*}{$\begin{array}{l}\text { Anti-Corruption } \\
\text { Education }\end{array}$} & 16. Understanding and concern for employees \\
\hline & & 17. Understanding and Concern of the second line of defense officers \\
\hline & & $\begin{array}{l}\text { 18. Understanding and Concern of Service Users, Customers, Goods } \\
\text { / Service Providers and the Community }\end{array}$ \\
\hline & \multirow{3}{*}{$\begin{array}{l}\text { Anti-Corruption } \\
\text { Organizational } \\
\text { Culture }\end{array}$} & 19. Formal and Informal Culture \\
\hline & & 20. Ethical Climate \\
\hline & & 21. Ethical Leadership \\
\hline & \multirow{3}{*}{$\begin{array}{l}\text { Corruption } \\
\text { Prevention System }\end{array}$} & 22. Corruption Risk Assessment \\
\hline & & 23. Corruption Control Policies and Measures \\
\hline & & 24. Whistleblowing System \\
\hline \multirow{4}{*}{$\begin{array}{l}\text { Handling } \\
\text { Corruption } \\
\text { Incidents } \\
\text { Corruption } \\
\text { Incidents }\end{array}$} & \multirow{2}{*}{$\begin{array}{l}\text { Corruption } \\
\text { Incidents }\end{array}$} & 25. Corruption level \\
\hline & & 26. Investigation and Recovery \\
\hline & \multirow[t]{2}{*}{ Corrective action } & 27. Strengthening corruption control \\
\hline & & 28. Benefits and Impacts \\
\hline
\end{tabular}




\section{Research Design}

\section{KORSUPGAH PROCESS:}

1) Cooperation agreement (PKS) KPK-BPKP 2) Focus Group Discussion (FGD); 3) Kopsurgah Launching 4) Kopsurgah Workshop; 5) Kopsurgah Guideline; 6) The BPKP Representative Kopsurgah Team conducts field activities on all Kopsurgah objects 7) Central Kopsurgah team (KPK-BPKP) carry out quality assurance8) Study Socialization; 9) Semiotic/Meeting; and 10) National Seminar on Korsup Prevention

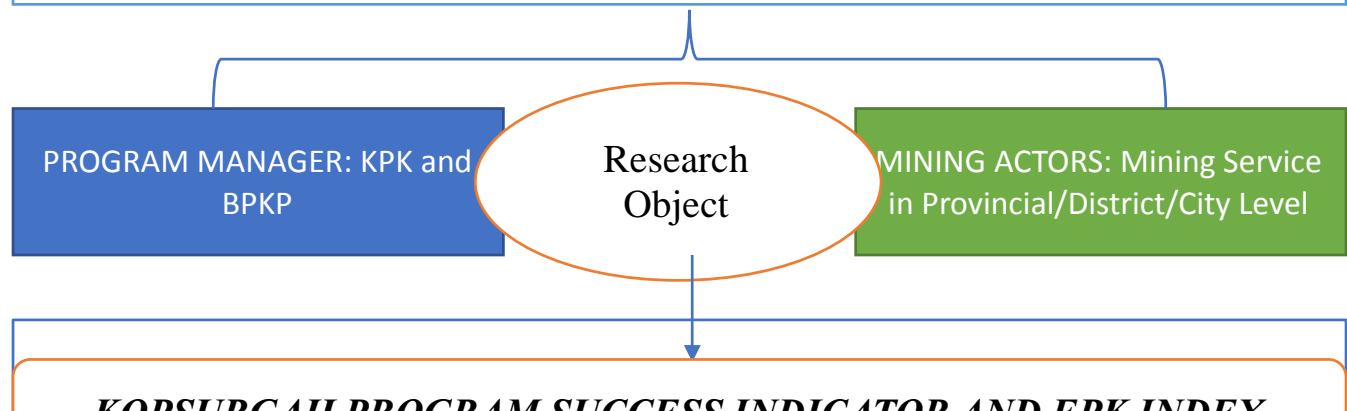

KOPSURGAH PROGRAM SUCCESS INDICATOR AND EPK INDEX

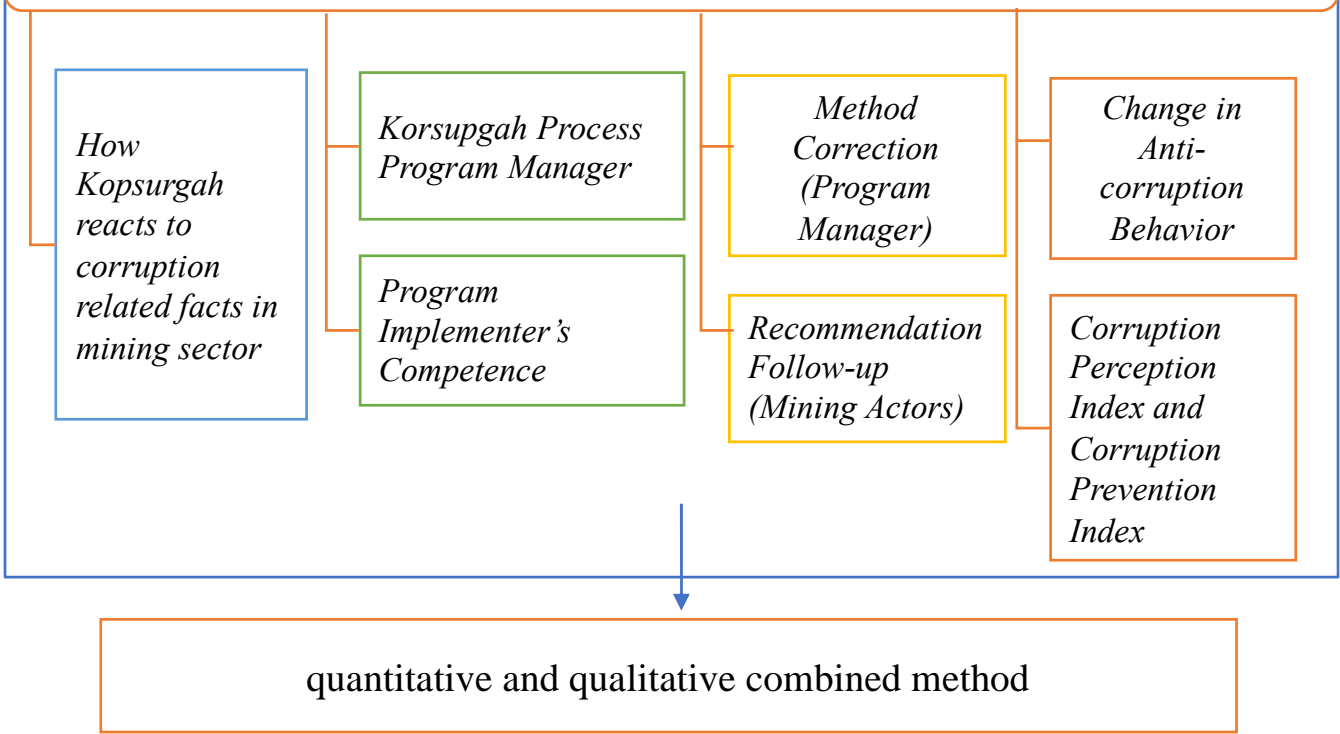

\section{Method:}

1. The use of questionnaire (perception) techniques and documentation analysis to describe a quantitative approach where data will be presented in a statistical descriptive. Then additional interpretations will be carried out with a qualitative approach.

2. The use of interview techniques, FGDs, and others deemed necessary to describe a qualitative approach based on research triangulation

Population: mining actors Sample: Several areas where corruption incidents are indicated in mining sector: Babel Province, South Sumatera and South Kalimantan

\section{Research Results and Discussion}

\section{Research Instrument}


Aspects that will be evaluated are 4 (four) components of Kirkpatrick's Model, namely reaction, learning, behavior, and result. Some of the information that mining actors and program implementers would like to obtain related to the level of the reaction include:

1) whether the objective of the korsupgah has been clearly stated?; 2) whether the activities carried out can define the goals to be achieved?; 3) are the facilities and infrastructure adequate to support the activities to be carried out?; 4) can all facilities and infrastructure be used easily and useful in carrying out activities ?; 5) Is there any prior dissemination or outreach by experts related to Korsupgah activities so that mining actors and program implementers understand the program substance?; 6) whether the program/activity implementation schedule that has been set has met the achievement of the objectives?;7) whether the Korsuppah program is related to the responsibilities of the main tasks and functions (tupoksi)?; and 8) Is there a desire to share information on the Korsupgah program with other colleagues?

Then, some information that would be obtained from mining actors and program implementers related to the level of learning includes: 1) What knowledge has been learned from the Korsupgah program ?; 2) what skills have been developed and updated ?; 3) Has the attitude of mining actors and program implementers changed?

Furthermore, some information to be obtained from mining actors and program implementers related to the level of behavior includes 1) Are there any changes in the behavior of mining actors and implementers of the Korsupgah program so that they have a high awareness of corruption prevention ?; 2) Is there any supervisory monitoring of changes in the behavior of mining actors and program implementers of Korsupgah?

Finally, some information to be obtained from mining actors and program implementers related to the level of results, among others, are 1) do the knowledge, skills, and attitude obtained from the Korsupgah program have an effect on work ?; 2) is there a change in anti-corruption behavior in the mining sector ?; 3) can corruption in the mining sector be prevented and reduced ?; and 4) how is the policy taken regarding the sustainability of the program, is it feasible to be maintained or continued, renewed or stopped?

\section{Data Collection Techniques and Procedures}

Data collection techniques and procedures in this study were carried out systematically by using observation, interviews, questionnaires, and documentation. Quantitative data collection used a questionnaire instrument for several program and mining managers in several sample locations. Meanwhile, qualitative data uses several methods such as interviews, FGDs and documentation, as well as other methods deemed necessary.

\section{Data Collection Method}

a. Interviews: non-test data collection method

The method combines the standardized open-ended interviews and the interview guide approach. The interview steps consist of 1) Planning for an Evaluation Interview; 2) Designing an Effective Interview: Writing Questions; 3) Designing an Effective Interview: Sequencing Questions; 4) Designing an Effective Interview: Piloting; and 5) Conducting an Effective Interview.(Jorge Mendez Seijas et al., 2018).

b. Questionnaire: Data collection technique using a set of questionnaires that have been compiled and then distributed to respondents to obtain the required data.

c. Focus Group: a certain type of group discussion (selected individuals or groups) that is expected to produce several informational perspectives on the issue or issue being discussed.

d. Documentation: official documents from institutions/organizations that have implemented Korsupgah. These documents include letters, data/information, notes, photographs of activities, files of reports that have been prepared by various parties regarding the object under study, and other relevant documents.

\section{Data Analysis Technique}

a. Data collection: The data collection stage was carried out through interviews, field observations and literature reviews.

b. Data transcription: At this stage, the results obtained from the collection of raw data are converted into written form as they are typed exactly as they are (verbatim).

c. Coding making: At this stage, certain parts of the transcript that have been made previously, which are important things and can become keywords, are coded.

d. Data categorization: Data categorization is that the researcher starts to simplify the data by binding key concepts (words) in a single quantity called a category.

e. Provisional concluding: Until this stage, researchers have been allowed to conclude, although they are still tentative, where these conclusions must be based entirely on data. 
f. Final concluding: To arrive at this stage, the researcher may repeat step one through step six many times before the researcher draws a conclusion and ends the research. The conclusion is drawn when the researcher feels that the data is saturated and each addition of new data only means redundancy.

\section{Research result}

The research was conducted in 3 (three) provinces, namely Bangka Belitung, South Sumatra, and South Kalimantan.

\begin{tabular}{|c|c|c|c|c|}
\hline No & Province/Satker & Population Target & $\begin{array}{l}\text { Respondent } \\
\text { Sample }\end{array}$ & \% Sampling \\
\hline \multirow[t]{7}{*}{1} & Bangka Belitung & & & \\
\hline & Environmental Services & 55 & 20 & $36,36 \%$ \\
\hline & ESDM Agency & 117 & 41 & $35,04 \%$ \\
\hline & Inspectorate & 40 & 13 & $32,50 \%$ \\
\hline & PTSP & 25 & 6 & $24,00 \%$ \\
\hline & BPKP (Korsupgah Team) & 15 & 7 & $46,66 \%$ \\
\hline & Bangka Belitung Total & 252 & 87 & $34,52 \%$ \\
\hline \multirow[t]{6}{*}{2} & South Kalimantan & & & \\
\hline & Environmental Services & 51 & 10 & $19,61 \%$ \\
\hline & ESDM Agency & 125 & 49 & $39,20 \%$ \\
\hline & Inspectorate & 34 & 15 & $44,12 \%$ \\
\hline & PTSP & 27 & 17 & $62,96 \%$ \\
\hline & South Kalimantan Total & 237 & 91 & $38,40 \%$ \\
\hline \multirow[t]{7}{*}{3} & South Sumatera & & & \\
\hline & Environmental Services & 70 & 22 & $31,43 \%$ \\
\hline & ESDM Agency & 115 & 30 & $26,09 \%$ \\
\hline & Inspectorate & 45 & 12 & $26,66 \%$ \\
\hline & PTSP & 36 & 6 & $16,66 \%$ \\
\hline & BPKP (Korsupgah Team) & 20 & 3 & $15,00 \%$ \\
\hline & South Sumatera Total & 286 & 73 & $25,52 \%$ \\
\hline 4 & Total $1+2+3$ & 775 & 251 & $32,39 \%$ \\
\hline
\end{tabular}

\section{Validity and Reliability Assesment}

EPK as a corruption prevention criterion (28 indicators) is sufficient or not to measure the effectiveness of corruption eradication. Based on regression using SEM AMOS, the reliability and validity scores were obtained as shown in the Table.

Data Table of Reliability and Validity Score

\begin{tabular}{|c|c|c|c|c|}
\hline VARIABLE & DIMENSION & INDICATOR & $\begin{array}{l}\text { REABILITY } \\
\text { SCORE }\end{array}$ & $\begin{array}{c}\text { VALIDITY } \\
\text { SCORE }\end{array}$ \\
\hline & Capacity & 1. Corruption risk management policy & 0,834 & 0,525 \\
\hline
\end{tabular}


Research Article

\begin{tabular}{|c|c|c|c|c|}
\hline VARIABLE & DIMENSION & INDICATOR & $\begin{array}{l}\text { REABILITY } \\
\text { SCORE }\end{array}$ & $\begin{array}{l}\text { VALIDITY } \\
\text { SCORE }\end{array}$ \\
\hline \multirow{11}{*}{$\begin{array}{l}\text { Corruption } \\
\text { Management } \\
\text { Capability }\end{array}$} & & $\begin{array}{l}\text { 2. Corruption risk management } \\
\text { organizational structure }\end{array}$ & 0,832 & 0,546 \\
\hline & & $\begin{array}{l}\text { 3. Anti corruption standards of } \\
\text { behavior }\end{array}$ & 0,840 & 0,639 \\
\hline & \multirow[t]{3}{*}{ Authority } & $\begin{array}{l}\text { 4. Decision making in managing the } \\
\text { risk of corruption (power to) }\end{array}$ & 0,869 & 0,548 \\
\hline & & $\begin{array}{l}\text { 5. Awareness to manage risk (power } \\
\text { within); }\end{array}$ & 0,866 & 0,647 \\
\hline & & $\begin{array}{l}\text { 6. Partnership and collaboration to } \\
\text { prevent corruption (power with) }\end{array}$ & 0,827 & 0,531 \\
\hline & \multirow[t]{3}{*}{ Competence } & $\begin{array}{l}\text { 7. Employee anti-corruption } \\
\text { competence }\end{array}$ & 0,860 & 0,598 \\
\hline & & $\begin{array}{l}\text { 8. Second line of defense officer anti- } \\
\text { corruption competence }\end{array}$ & 0,872 & 0,768 \\
\hline & & $\begin{array}{l}\text { 9. Service users, customers. Provider } \\
\text { of goods/services and Public anti- } \\
\text { corruption competence }\end{array}$ & 0,842 & 0,768 \\
\hline & \multirow[t]{3}{*}{ Ability } & 10. Human Resources & 0,745 & 0,844 \\
\hline & & 11. Finance & 0,770 & 0,736 \\
\hline & & 12. Infrastructure & 0,712 & 0,507 \\
\hline \multirow{11}{*}{$\begin{array}{l}\text { Implementation } \\
\text { of Corruption } \\
\text { Prevention } \\
\text { Strategy }\end{array}$} & \multirow[t]{3}{*}{ Integrity } & 13. Individual Integrity & 0,878 & 0,537 \\
\hline & & 14. Organizational Integrity & 0,843 & 0,597 \\
\hline & & 15. Institutional Integrity & 0,814 & 0,720 \\
\hline & \multirow[t]{3}{*}{$\begin{array}{l}\text { Anti Corruption } \\
\text { Education }\end{array}$} & $\begin{array}{l}\text { 16. Employee's Understanding and } \\
\text { Concern }\end{array}$ & 0,861 & 0,502 \\
\hline & & $\begin{array}{l}\text { 17. Second line of defense officer's } \\
\text { Understanding and Concern }\end{array}$ & 0,790 & 0,553 \\
\hline & & $\begin{array}{l}\text { 18. Service users, Customers, } \\
\text { Goods/Service Providers' } \\
\text { Understanding and Concern }\end{array}$ & 0,725 & 0,574 \\
\hline & \multirow{3}{*}{$\begin{array}{l}\text { Anti Corruption } \\
\text { Culture } \\
\text { Organization }\end{array}$} & 19. Formal and Informal Culture & 0,792 & 0,589 \\
\hline & & 20. Ethics Climate & 0,741 & 0,608 \\
\hline & & 21. Ethical Leadership & 0,654 & 0,690 \\
\hline & \multirow{2}{*}{$\begin{array}{l}\text { Corruption } \\
\text { Prevention } \\
\text { System }\end{array}$} & 22. Corruption Risk Assessment & 0,712 & 0,679 \\
\hline & & $\begin{array}{l}\text { 23. Corruption Control Policy and } \\
\text { Action }\end{array}$ & 0,829 & 0,560 \\
\hline
\end{tabular}




\begin{tabular}{|l|l|ll|c|c|}
\hline \multirow{2}{*}{ VARIABLE } & \multirow{2}{*}{ DIMENSION } & \multicolumn{1}{|c|}{ INDICATOR } & $\begin{array}{c}\text { REABILITY } \\
\text { SCORE }\end{array}$ & $\begin{array}{c}\text { VALIDITY } \\
\text { SCORE }\end{array}$ \\
\hline & & 24. & Whistleblowing System & 0,847 & 0,518 \\
\hline $\begin{array}{l}\text { Corruption } \\
\text { Incident } \\
\text { Handling }\end{array}$ & $\begin{array}{l}\text { Corruption } \\
\text { Incident }\end{array}$ & 25. & Corruption Level & 0,788 & 0,503 \\
\cline { 2 - 6 } & $\begin{array}{l}\text { Corrective } \\
\text { Action }\end{array}$ & 26. & Investigation and Loss Recovery & 0,642 & 0,533 \\
\cline { 2 - 6 } & 28. & Corruption Control Strengthening & 0,724 & 0,695 \\
\hline
\end{tabular}

The table above (validity score) shows the results of the Standardized Loading Estimate output in general is statistically significant because the loading value is above 0.5 . Therefore, the indicators used are valid for use in further research processes.

The table above (reliability score) shows that all dimensions have a reliability value $>0.70$ indicating good reliability, except for indicators of ethical leadership, investigation and loss recovery, and also benefit and impact, each with 0,654 reliability, 0,642 and 0,688 is still acceptable (reliability $0,600-0,700$ ) provided that the validity of the indicator is good (Ghozali, 2017; 144), so that it can be concluded that all indicators are reliable.

\section{Hypothesis Testing}

Hypothesis testing is conducted to test the effect of the capability variable on Handling, Application of Handling and Application of Capability. This test is carried out based on the Critical Ratio (CR) of the regression weight results of SEM AMOS processing, with the results shows that CR calculation for each variable with a value between 3.155 and 4.703. Testing is done by comparing CR with the Hypothesis limit, namely 1.96 with alpha = 0.05 , those are:

a. The estimate used to test the Capability to Handling is a CR value of 3.155 with a probability of 0.002 , so when compared with $\mathrm{H} 0$, namely CR> 1.96 and probability $<0.05$, then the CR value is greater than 1.96 and alpha is less than 0.05 , so that it can be said to meet the requirements to accept the hypothesis that Capability has a significant positive effect on Handling.

b. The estimate used to test the Application to Handling is a CR value of 4.058 with probability ***, so that when compared with $\mathrm{H} 0$, namely CR $>1.96$ and probability $<0.05$, then the CR value is greater than 1.96 and alpha is smaller than 0.05 . So that it can be said to meet the requirements to accept the hypothesis that Application has a significant positive effect on Handling.

c. The estimate used to test the Application to Capability is a CR value of 4.703 with probability ***, so that when compared to H0, namely CR> 1.96 and a probability of 0.05 , then the CR value is greater than 1.96 and alpha is less than 0.05 , so it can be said to be eligible to accept the hypothesis that Application has a significant positive effect on Capability.

\section{Korsupgah ATT Results Kirkpatrik Model Evaluation (Descriptive Statistic)}

The average statistic shows that the respondent's reaction to the Korsupgah program is positive (agree or value $<2.0$ on the Likert scale) where the respondent understands the importance of the Korsupgah program. In addition, the Korsupgah Program is needed to improve mining governance and reduce the level of corruption and provide added value to the governance (business process) of the mining sector through increased competence (knowledge and skills) and synergies in preventing corruption.

For questions which the average is > than 2.35 (which indicates respondent's disagreement) what needs to be concerned is:

a. There is political support (political will) from the regional head to follow up on the findings of the Korsupgah ATT

This shows that there is still no strong will from the leadership of the regional head to follow up on the results of the Korsupgah ATT. This reluctance was caused by the ignorance of regional heads regarding the Korsupgah ATT issue or their reluctance because it would create instability in their regions. 
b. We have followed up all the findings of the Korsupgah ATT Program

This shows that there are still auditors who have not followed up on the recommendations of all the Korsupgah ATT results. They only followed up on some of the recommendations on the ATT results. The main cause of the findings that were not followed up completely was the involvement of a third party as the person in charge of following up the ATT results.

c. In general satisfied with ATT Kosuprgah Implementation

This shows that there are still auditors who are not satisfied with the results of the Korsupgah ATT, both the process and the results. This dissatisfaction was caused by their dissatisfaction with the implementation of the Korsupgah program which had not provided strategic recommendations.

d. Mining players have adequately understood the ATT results

This shows that there are still auditors who do not understand the results of the Korsupgah ATT both on their findings and recommendations. This lack of understanding was caused by their ignorance of the methodology used by the auditors so that the auditors gave conclusions and recommendations that they felt were not relevant.

e. Mining players agree with the results of the ATT

This shows that there is still something that has not been agreed upon both the findings and recommendations of the Korsupgah ATT. This is a common concern of both auditors and auditors to be professional in carrying out their respective roles.

f. The Audit Team understands adequate governance in the Mining Sector.

This shows that there is still a Korsupgah ATT Audit Team that does not yet understand governance in the Mining Sector. This is the concern of auditors to improve understanding and competence as well as to be professional in carrying out their roles and main tasks.

g. My boss doesn't support / encourage us to make changes

For questions that are negative in nature, this shows that there are still superiors who are resistant to change. This is an anomaly of change management that encourages every member of the organization to make changes.

\section{Conclusion and Suggestions}

\section{Conclusion}

The research and the analysis results that have been carried out using the respondent data of civil servants in the work units of the Environmental Service, ESDM Service, Inspectorate, and PTSP in Bangka Belitung Province, South Kalimantan and South Sumatra Provinces and the BPKP Kosupgah Team, totalling 251 people, using 4 steps Kirkpatrick model can be concluded as follows:

1. Reaction shows that the reaction of mining actors to ATT is adequate (Prevention).

2. Learning shows that the learning process of the Korsupgah (Prevention) program is already running.

3. Behavior shows changes in behavior to follow up on the findings of the Korsupgah ATT results.

4. The results show that the Corruption Perception Index is still low, Public Complaints still exist and cases of mining corruption still exist.

Taking into account the results of the research and discussion that has been carried out, it shows that the instruments and methodologies of Korsupah need to be improved and not as we expected, This can be seen from the fact that there are still complaints from the public regarding corruption cases, Therefore we need other criteria for preventing corruption. There are 28 (twenty eight) criteria for corruption prevention, namely: 1) corruption risk management policy, 2) corruption risk management structure, 3) anti-corruption behavior standards, 4) decision making in corruption risk management, 5) awareness to manage risks, 6 ) Partnership and collaboration to prevent corruption, 7) Anti-corruption competence of employees, 8) Anti-corruption competence of second line of defense officers, 9) Anti-corruption competence of Customer Service Users, Goods / Service Providers and the Community, 10) Human Resources, 11) Finance, 12) Infrastructure, 13) Individual integrity, 14) Organizational integrity, 15) Institutional integrity, 16) Understanding \& concern of employees, 17) Understanding and concern of second line of defense officers, 18) Understanding and concern for service users, customers, providers of goods / services and society, 19) Formal and informal culture, 20) Ethical climate, 21) Ethical leadership, 22) Assessment of risk of corruption, 23) Policies and measures to control corruption, 24) 
Whistleblowing system, 25) Level of corruption, 26) Investigation and recovery of losses, 27) Strengthening corruption control, and 28) Benefits and impacts.

\section{Suggestions}

From the conclusions obtained, to improve the effectiveness of corruption prevention as follows:

1. Comprehensive and systematic evaluation, using at least 28 (twenty-eight indicators).

2. Identify each indicator, so it is clear what needs to be improved if Kirkpatrick's Reaction, Learning and Behavior are not in line with the results.

3. The evaluation of the effectiveness of corruption prevention is carried out systematically and continuously.

\section{Referensi}

1. Abutabenjeh, Sawsan dan Raed Jaradat. "Clarification of research design, research methods, and research methodology: A guide for public administration researchers and practitioners. ” Teaching Public Administration, 2018.

2. Alatas, Syed Hussein. Sosiologi Korupsi, Sebuah Penjelajahan dengan Data Kontemporer. Jakarta: LP3ES, 1982).

3. Ali, Muhammad, Metode Penelitian Pendidikan. Bandung: Angkasa, 1985).

4. Araral, Eduardo Jr., Scott Fritzen, Michael Howlett, M Ramesh, Xun Wu. Routledge Handbook of Public Policy. Abingdon: Routledge, 2013.

5. Arifin, Zainal. Metodologi Penelitian Pendidikan Filosofi, Teori dan Aplikasinya. Surabaya: Lentera Cendika, 2010.

6. Auerbach, Charles dan Wendy Zeitlin. Making Your Case:Using R for Program Evaluation. New York: Oxford University Press, 2015.

7. Badan Pengawasan Keuangan dan Pembangunan. Strategi Pemberantasan Korupsi Nasional. Jakarta, 1999.

8. Badiru, Adedeji B. Triple C Model of Project Management: Communication, Cooperation, and Coordination. Boca Raton : Taylor \& Francis Group, 2008.

9. Balthasar, Andreas. “Critical Friend Approach: Policy Evaluation Between Methodological Soundness, Practical Relevance, and Transparency of the Evaluation Process." German Policy Studies, Vol. 7, No. 3, 2011.

10. Bauckaert, Greert, B. Guy Peters and Koen Verhoest, The Coordination of Public Sector Organizations: Shifting Patterns of Public Management, New York: Palgrave Macmillan, 2010.

11. Bray, Lucy. "The differences between audit, service evaluation and research." Nursing Children and Young People Volume 27 Number 1, 2015.

12. Bryfonski, Lara, Counducting Focus Groups For Evaluation, Georgetown University Press, 2018.

13. Clammer, John, Corruption, Development, Chaos and Social Dissorganisation: Sociological reflections on corruption and its social basis, Canberra: ANU Press, 2012.

14. Cummins, Carol O. et.al. "Development of Review Criteria to Evaluate Health Behavior Change Websites. " Journal of Health Psychology Vol 8(1), 2003.

15. Dietric, Perttu, Jaakko Kujala, dan Karlos Artto, "Inter-Team Coordination Patterns and Outcomes in Multi-Team Projects, ” Project Management Journal, Vol. 44, No. 6, 2013.

16. Dunois, David D, William J. Rothwell, Deborah Jo King Stern, Linda K. Kemp, “Competency-Based Human Resource Management”, Davies-Black Publishing Mountain View, California, First Edition, 2004.

17. Emir, Metodologi Penelitian Pendidikan Kuantitatif \& Kualitatif, RajaGrafindon Persada, Jakarta, Cetakan ke-6, 2012.

18. Falender, Carol A. and Edward P. Shafranske. Clinical Supervision A Competency - Based Approach. Washington, DC: American Psychological Association, 2004. 
19. Fitriyanti, Reno. “Pertambangan Batubara: Dampak Lingkungan, Sosial dan Ekonomi, ” Jurnal Redoks, Volume 1, Nomor 1, 2016.

20. Fitzpatrick Jody L., James R. Sanders dan Blaine R. Worthen. Program Evaluation: Alternative Approaches and Practical Guidelines, fourth edition. New Jersey: Pearson Education, Inc., 2011).

21. Gardet, Elodie dan Shady Fraiha. "Coordination Modes Established by the Hub Firm of an Innovation Network: The Case of an SME Bearer.” Journal of Small Business Management 50 (2), 2010.

22. Geert Bouckaert, B. Guy Peters and Koen Verhoest. The Coordination Of Public Sector Organizations: Shifting Patterns of Public Management. New York: Palgrave Macmillan, 2010.

23. Gruba, Paul, Mónica S. Cárdenas-Claros, Ruslan Suvorov, dan Katherine Rick. Blended Language Program Evaluation. New York: Palgrave Macmillan, 2016.

24. Guyadeen, Dave dan Mark Seasons, “Evaluation Theory and Practice: Comparing Program Evaluation and Evaluation Planning, “ Journal of Planning Education and Research, 2016.

25. Ghozali, Imam, Desain Penelitian Kuantitatif \& Kualitatif: untuk Akuntansi, Bisnis, dan Ilmu Sosial Lainnya, Yoga Pratama, Semarang, 2016.

26. Ghozali, Imam, Model Persamaan Struktural: Konsep dan Aplikasi dengan Program AMOS 24, Edisi 7, Badan Penerbit Universitas Diponegoro, Semarang, 2017.

27. Hamzah, Andi. Pemberantasan Korupsi Melalui Pidana Nasional dan Internasiona. Jakarta, PT Raja Grafindo Perkasa, 2005.

28. Hovik, Sissel and Gro Sandkjaer Hanssen, "The Impact of Network Management and Complexity On Multi-Level Coordination”, Public Administration, Vol. 93, No. 2, 2015.

29. Im, Eun-Ok. “The Current Status of Theory Evaluation in Nursing.” Discussion Paper, 2015.

30. Irawan, Prasetya. Penelitian Kualitatif dan Kuantitatif Untuk Ilmu-Ilmu Sosial. Depok: Fisip UI, 2006.

31. Kamus Besar Bahasa Indonesia.

32. Kellermann, A. Joanne, Jakob de Haan, dan Femke de Vries, Financial Supervision in the $21^{\text {st }}$ Century. Verlag Berlin Heidelber, 2013.

33. Knutsen, Carl Henrik, Andreas Kotsadam, dan Eivind Hammersmark Olsen, "Mining and Local Corruption in Africa," American Journal of Political Science, 2016.

34. Klitgaard, Robert. Membasmi Korupsi Terjemahan. Jakarta: Yayasan Obor Indonesia, 2005.

35. Komisi Pemberantasan Korupsi, Laporan Tahunan, Tahun 2012.

36. Kim, Amy I., John McE. Davis, Questionnaires for Evaluation, Georgetown University Press., 2018.

37. Levin, Ginger and J. LeRoy Ward, Program Management Complexity: A Competency Model, (Boca Raton: Auerbach Publications Taylor and Francis Group, 2011) hh.20-27.

38. Marsal, Ian E., “A Survey of Corruption Issues in the the Mining and Mineral Sector,” IIED and WBCSD, 2002.

39. Mears, Daniel P., American Criminal Justice Policy, An Evaluation Approach to Increasing Accountability and Effectiveness. New York: Cambridge University Press, 2010.

40. More, Harry W. PhD dan Larry S. Miller PhD. Effective Police Supervision Seventh Edition. Abingdon: Routledge, 2015. 
41. Newcomer, Kathryn E., Harry P. Hatry \& Joseph S. Wholey. Handbook of Practical Program Evaluation, Fourth Edition. New Jersey: Jossey-Bass, 2015.

42. Nkwake, Apollo M., Credibility, Validity, and Assumptions in Program Evaluation Methodology. Switzerland: Springer, 2015.

43. Ortega, Bienvenido, Antonio Casquero, dan Jesús Sanjuán. "Growth in Human Development: the Role of corruption," Journal of international development,. J. Int. Dev. 26, 2014.

44. Øvretveit, John. Action Evaluation of Health Programmes and Changes: A handbook for a user-focused approach. Abingdon: Radcliffe Medical Press Ltd, 2002.

45. Praslov, Ludmila. “Adaptation of Kirkpatrick's Four Level Model of Training Criteria to Assessment of Learning Outcomes and Program Evaluation in Higher Education,” Educ Asse Eval Acc, 2010.

46. Resosudarmo, Budy P., Ariana Alisjahbana dan Ditya Agung Nurdianto. "Energy Security in Indonesia”, MAC/CESHI, 2011.

47. Revolida, R.Yunianto. "Peningkatan Nilai Tambah Pertambangan”. Warta Mineral, Batubara \& Panas Bumi, 2010.

48. Rokhim, Abdul, “Kegiatan Usaha Pertambangan Vs Kerusakan Lingkungan Hidup”, Dinamika Hukum, FH Unisma Malang, Vol. XVII No. 35, 2012.

49. Rossi, Peter H., Howard E. Freeman Mark W. Lipsey, Evaluation A Systemic Approach London: Sage Pubication, 1985.

50. Royse, David, Bruce A. Thyer, dan Deborah K. Padgett. Program Evaluation An Introduction, Fifth Edition. Belmont: Wadsworth, Cengage Learning, 2010.

51. Renn, Ortwin, Andreas Klinke, Marjolein van Asselt, "Coping with Complexity and Ambiguity in Risk Governance: A Synthesis", AMBIO (2011) 40: 231-246.

52. Rosa, Enugene A, Ortwin Renn and Aaron M. McCright, "The Three Companions of Risk: Complexity, Uncertainty, and Ambiguity”, Temple University Press (2014).

53. Sanghi, Seema, “The Handbook of Competency Mapping, Understanding, Designing and Implementing Competency Models in Organizations", Response Books, Business books SAGE B 1/I1, Mohan Cooperative Induatrial Area Mathura Road, New Delhi, Second Edition, 2007.

54. Stevahn, Laurie, et.al. “Establishing Essential Competencies for Program Evaluators”, American Journal of Evaluation, Vol. 26 No. 1, March 2005

55. Siriwardane, Harshini P., Billy Kin Hoi Hu, and Kin Yew Low, "Skills, Knowledge, and Attitudes Important for Present-Day Auditor's", International Journal of Auditing, 18:193-205, 2014.

56. Salas, Eduardo, Marissa l. Shuffler, Amanda l. Thayer, wendy l. Bedwell, and Elizabeth H. Lazzara. “Understanding and Improving Teamwork In Organizations: A Scientifically Based Practical Guide”, Human Resource Management”, Vol 54, No. 4. 2014.

57. Shermon, Ganesh, "Competency Based HRM: A Strategic Resource for Competency Mapping, Assessment and Development Centres". Tata McGraw-Hill Publishing Company Limited, New Delhi, 2004.

58. Silberman, Mel and Elaine Biech, “Active Training: A Handbook of Techniques, Designs, Case Examples, and Tips". Library of Congress Cataloging-in-Publication Data is on file, Fourth Edition, 2015. 
59. Saltiel, David. “Supervision: A Contested Space for Learning and Decision Making ". Qualitative Social Work, 2016.

60. Schuck, Caroline dan Jane Wood. Inspiring Creative Supervision. London: Jessica Kingsley Publishers, 2011.

61. Sekaran, Uma dan Roger Bougie. Research Methods for Business: A Skill-Building Approach. West Sussex: John Wiley \& Sons Ltd, 2016.

62. Shao, Jingting, Ralf Müller, dan J. Rodney Turner. "Measuring program success.” Project Management Journal, 2010.

63. Shipman, Stephanie. "General Criteria for Evaluating Social Programs Evaluation Practice." GAO vol. 10, 1, 1989.

64. Singleton Tommie. Fraud Auditing and Forensic Accounting, Third Edition. Canada: John Wiley \& Sons, Inc, 2006.

65. Sugiyono. Metode Penelitian Kuantitatif, Kualitatit dan R \& D. Bandung: CV Alfabeta, 2008.

66. Stufflebeam, Daniel L. dan Chris L. S. Coryn. Evaluation Theory, Models, and Applications, Second Edition. San Francisco: Jossey-Bass, 2014.

67. Seijas, Jorge Mendez, Janire Zalbidea, Cristi Vallejos, Conducting Evaluation Interviews, Georgetown University Press., 2018.

68. Vernon, Henderson, J. and Ari Kuncoro, “Corruption in Indonesia”, National Bureau of Economic Research, No. W10674, 2004.

69. Warhurst, Alyson. “The Limitations of Environmental Regulation in Mining," Mining and The Environment International Perspectives On Public Policy, 2011, hh.,133-169.

70. Watkins Ryan, Doug Leigh, Rob Foshay dan Roger Kaufman, 1998, “Kirkpatrick Plus: Evaluation and Continuous Improvement with a Community Focus, ” Educational Technology Research and Development, 1998.

71. Wibowo, Manajemen Kinerja, Jakarta:Radja GRafindo Perkasa, 2007.

72. Yulianto, Agus dan Yulianto Tri Nugroho. "RKAB Bentuk Komitmen Perusahaan Tambang Terhadap Negara”, Warta Mineral, Batubara \& Panas Bumi”, 2010.

73. Zainal, Veithzal Rivai, Islamic Human Capital Managemen, Manajemen Sumber Daya Insani, PT. RajaGrafindo Persada Jakarta, Edisi Revisi 2014. 